\title{
A renovação da linguagem do Circo-Teatro no Brasil e seu reflexo no teatro contemporâneo.
}

\section{Flora Ainá Rossi de Araujo*, Larissa de Oliveira Neves Catalão.}

\begin{abstract}
Resumo
Esta pesquisa de cunho teórico analisou o Circo-Teatro brasileiro, suas relações com o teatro experimental contemporâneo e o melodrama policial A ré misteriosa, texto de Alexandre Bisson e tradução de Gomes Cardim, que narra a história de uma mulher que abandona marido e filho após ser acusada de assassinar o amante. Será analisada a encenação do grupo Os Fofos Encenam, ocorrida em 2013, sob a direção de Fernando Neves.
\end{abstract}

\section{Palavras-chave: \\ Circo-Teatro, Os Fofos Encenam, A ré misteriosa.}

\section{Introdução}

O Circo-Teatro surgiu no final do século XIX e início do século XX. Naquela época algumas companhias já apresentavam espetáculos teatrais com características típicas dessa linguagem no circo, mas quem a difundiu e popularizou foi o palhaço Benjamin de Oliveira (Cf. Silvia, 2007) ${ }^{1}$.

Os Fofos Encenam é uma companhia teatral paulistana que estuda o Circo-Teatro. Eles produzem espetáculos completamente reestruturados, se comparados com 0 Circo-Teatro tradicional. Em 2013, o grupo iniciou o projeto Baú da Arethuzza, que apresentou espetáculos diversos de Circo-Teatro. Um desses espetáculos foi 0 melodrama policial $A$ ré misteriosa, que conta a história de uma mulher, Dominique, que, depois de um escândalo extraconjugal e pressionada pela sogra, decide abandonar a família. Vivendo na marginalidade, acaba conhecendo Frederico La Roque, que vira seu amante. Juntos vão para Paris onde Dominique assassina Frederico. O caso se deu quando o amante ameaçou a mulher afirmando que contaria para a família dela que ela estava viva. Em seu julgamento Dominique será defendida pelo próprio filho, que não imagina a verdadeira identidade da ré misteriosa.

Esta pesquisa, portanto, tem o objetivo de analisar o melodrama policial $A$ ré misteriosa a fim de compreender o diálogo entre o Circo-Teatro e a cena de teatro atual, para compreender a herança, a renovação e as influências dessa linguagem para 0 teatro na contemporaneidade e em especial no grupo Os Fofos Encenam.

\section{Resultados e Discussão}

No início da pesquisa foi feito um levantamento histórico do circo e do Circo-Teatro e a partir dele foi possível comprovar a importância dos acontecimentos históricos, sociais, políticos e econômicos para o fazer na cultura popular, portanto, para o Circo-Teatro. Além disso, pesquisou-se as primeiras experimentações do teatro de grupo com o Circo-Teatro, realizadas pelo Grupo de Teatro Mambembe. O foco, porém, foi a análise da montagem de $A$ ré misteriosa, de 2013. Foram escolhidos para análise mais detida: atuação, cenário, figurino, maquiagem e trilha sonora.

A atuação foi um dos elementos mais essenciais para o trabalho dos Fofos. $O$ estudo aprofundado dos personagens-tipo revelou que o público do século $X X I$ não se emociona com a mesma atuação feita no CircoTeatro tradicional, que era muito exagerada e dramática. O público moderno não acredita nela e poderia inclusive achar cômica, ele se emociona com o melodrama se a atuação for realista e menos saturada. Os Fofos investiram nisso, trocando a atriz que fez a personagem principal, que originalmente seria interpretada por uma atriz do tipo Dama-Central por uma Sobrete.

O cenário foi outro elemento inovador de extrema importância, ele foge completamente da ideia de cenário tradicional, com telões pintados, elementos coloridos e exuberantes e o público numa semi-arena. Ele é simples e minimalista, com objetos-chave que ambientalizam os diferentes cômodos. Além disso, utilizaram as paredes do próprio teatro para criar diferentes cores e texturas nos ambientes retratados na história. $O$ público situa-se no meio do palco e acompanha a narrativa que acontece a sua volta $\left(360^{\circ}\right)$.

Também foi discutida a questão da mulher na peça, principalmente Dominique, que depois de um adultério não tem outra opção senão viver na marginalidade. Essa questão é revista pelos Fofos. Essa peça apresentada atualmente possibilita uma nova leitura sobre a mesma história, na qual o vilão não é o marido de Dominique por rejeitá-la ou sua sogra pela mesquinhez e falta de empatia. $O$ vilão da história não é um indivíduo e sim a sociedade, que oprime Dominique e a coloca na situação de vítima.

\section{Conclusões}

Conclui-se que a encenação de $A$ ré misteriosa, em 2013 pelo grupo Os Fofos Encenam recupera elementos do Circo-teatro tradicional como maquiagem e figurino e recria outros elementos como a forma de atuação e o cenário para proporcionar ao espectador de hoje o impacto emocional semelhante ao que o Circo-Teatro e o melodrama geravam na plateia de meados do século $X X$. $O$ grupo consegue, com sensibilidade, reinventar e ao mesmo tempo reiterar a linguagem teatral circense, num espetáculo experimental. Essa peça é exemplo de como o teatro brasileiro é resultado de um caminhar constante de ricas linguagens cênicas que, quando repensadas pelo teatro de grupo, ganham novos matizes, capazes de surpreender e encantar o público.

\section{Agradecimentos}

Esta pesquisa foi fomentada pelo Conselho Nacional de Desenvolvimento Cientifico e Tecnológico (CNPq) no Programa Institucional de Bolsa de Iniciação Científica (Pibic).

\footnotetext{
Silvia, Ermínia. Circo-teatro: Benjamin de Oliveira e a teatralidade circense no Brasil. São Paulo: Editora Altana Ltda, 2007, 402p.
} 